\title{
FEATURES OF MORPHOLOGICAL REARRANGEMENTS OF STRUCTURAL COMPONENTS IN THE RAT PINEAL GLAND UNDER THE IMPACT OF HEAVY METAL SALTS ${ }^{*}$
}

\author{
N. B. Hryntsova ${ }^{1}$, A. M. Romanyuk ${ }^{1}$, I. Hodorova ${ }^{2}$, L. I. Karpenko ${ }^{1}$, \\ V. I. Bumeister ${ }^{1}$, S. M. Dmytruk ${ }^{1}$, S. S. Zaitseva ${ }^{1}$ \\ ${ }^{1}$ Sumy State University, Medical Institute, Sumy, Ukraine \\ ${ }^{2}$ Pavel Josef Shafarik University in Kosice, Kosice, Slovak Republic \\ natalia.grintsova@gmail.com
}

Industrial production development and rapid urbanization cause a significant anthropogenic and technogenic load on the environment by increasing the amount of chemical elements in the air, soil, water resources, living organisms and plants [1]. The leading pollutants are heavy metals, due to their harmful effects on the health of living organisms, toxicity and the ability to accumulate in humans and animals [2]. Increased content of heavy metals in the body leads to the conformation of molecules in the cell [3]. It contributes to impairment of metabolic reactions, damage to membranes, reduced cell antioxidant protection, impaired protein and nuclear acids synthesis, adversely affects physiological activity of living bodies [4]. Today, an important environmental problem of some northern regions of Ukraine is the accumulation of heavy metal salts (zinc, chromium, lead, manganese, copper and iron) in the soil, water and air, which is observed in various combinations depending on the region and causes adverse effects on population's health. Such a negative impact determines the development and course of oncological pathology, disorders of the body homeostasis and morphological transformations in various tissues. The endocrine system together with the immune and nervous systems maintains homeostasis in the body. The central link, in particular the pineal gland, is involved in triggering a stress response, limiting its further development preventing adverse effects on the body [5]. Today, the pineal gland is defined as a photoneuroendocrine transducer that forms an integral part of the brain and carries information about circadian rhythms, thereby further connecting the outside world with the internal biochemical and physiological needs and functions of the human body [6]. As of today, the various exter-

* The work was performed within the framework of the scholarship of the Slovak Republic Government (2020) and in accordance with the research plan of the Medical Institute at Sumy State University and is part of the planned research project at the Department of Pathological Anatomy «Morphogenesis of general pathological processes» (state registration No. 013U003315) and «Regularities of age and constitutional morphological changes under the conditions of exposure to endo- and exogenous factors and ways of their correction» (No. 0113U001347).

The authors guarantee their responsibility for objectivity of the information provided.

The authors guarantee the absence of conflict of interest and their own financial interest.

The manuscript was received by the editorial staff 28.05.2021. 
nal and internal factors impact on the pineal gland: antipsychotic therapy and neuroleptics [7], light and radiation in the experiment [8], fluorine [9] has been extensively studied. The scientific novelty of the obtained results is to obtain new morphological data on the functioning of the rat's pineal gland under the influence of a mixture of heavy metals salts. For the first time on the basis of experimental material a comprehensive morphometric study of the pineal gland's structural components was carried out under the influence of a mixture of heavy metal salts that pollute water resources of the northern regions of Ukraine after the Chernobyl accident.

The purpose the study was to elucidate the morphological and morphometric rearrangements the structural components changes in the pineal gland of mature rats under the influence of heavy metal salts.

\section{MATERIALS AND METHODS}

The experiment was performed on 12 white mature male rats weighing 200-250 g at the age of 7-8 months, which were divided into 2 groups (group 1 control and group 1 experimental). Animals of both groups were kept in normal vivarium conditions, where equal conditions of management, nutrition, proper care and natural lighting (day/night) with a constant ambient temperature $\left(20-22{ }^{\circ} \mathrm{C}\right)$ were maintained. The animals had free access to drinking water. Animals of the experimental group were simulated microelementosis by adding to drinking water a mixture of heavy metal salts for 30 days: zinc $\left(\mathrm{ZnSO}_{4} 7 \mathrm{H}_{2} \mathrm{O}\right)-$ $5 \mathrm{mg} / \mathrm{L}$, copper $\left(\mathrm{CuSO}_{4} 5 \mathrm{H}_{2} \mathrm{O}\right)-1 \mathrm{mg} / \mathrm{L}$, iron $\left(\mathrm{FeSO}_{4}\right)-10 \mathrm{mg} / \mathrm{L}$, manganese $\left(\mathrm{MnSO}_{4}\right.$ $\left.5 \mathrm{H}_{2} \mathrm{O}\right)-0.1 \mathrm{mg} / \mathrm{L}$, lead $\left(\mathrm{Pb}\left(\mathrm{NO}_{3}\right)_{2}\right)-0.1 \mathrm{mg} / \mathrm{L}$, and chromium $\left(\mathrm{K}_{2} \mathrm{Cr}_{2} \mathrm{O}_{7}\right)-0.1 \mathrm{mg} / \mathrm{L}$. The selected concentration of salts in the mixture was due to the presence of similar concentrations of these salts in the soil and drinking water of some regions of Ukraine according to the literature [5]. Animals were kept and manipulated in compliance with national and international norms on bioethics. Groups of experimental animals were sacrificed after previous thiopental anesthesia (at the dose of $30-40 \mathrm{mg} / 10 \mathrm{~g}$ body weight) on the $30^{\text {th }}$ day of the experiment (Minutes No. 8 of 17.11.2020 of the Bioethics Commission of Sumy State University).

The subject of the study was the pineal gland of experimental and control animals.
To study morphological changes of the pineal gland's structural components, the usual methods of microanatomical (histological) study were used. General morphological and morphometric analysis was performed using a light optical microscope "Leica DM 500" with lenses $\mathrm{x} 4, \mathrm{x} 10, \mathrm{x} 40$, oculars 7,10 . Photo documentation of the results was performed with a digital video camera "Leica DM IC C50 HD Camera» (Leica Microsystems, Germany, 2010). To determine the morphofunctional features of the pineal gland's pinealocytes the following morphometric parameters were used: large and small diameters of cells and cell nuclei $(\mu \mathrm{m})$, cross-sectional area of pinealocytes and their nuclei $(\mu \mathrm{mI})$, cytoplasm's area $(\mu \mathrm{mI})$, nuclearcytoplasmic ratio, pinealocytes' optic density of the nucleus and cytoplasm (RU). In order to study the ratio of pinealocytes and glial elements in the pineal gland, the absolute number of pinealocytes, astrocytic glia and gliocytoneuronal index were determined. To determine the morphological rearrangements in the pineal gland's vascular bed, the area of the vessels $(\mu \mathrm{mI})$ was determined. Statistical processing of the obtained data was performed by parametric method of variation statistic using the software package STATISTICA v.10 (StatSoft Inc., USA). Data are presented as the mean (X) \pm standard deviation (SD), using the Student's t test. The error probability of less than $5 \%$ $(p \leq 0.05)$ was considered sufficient.

\section{RESULTS AND THEIR DISCUSSION}

After 30 days of exposure to a complex of heavy metal salts, the pineal gland of rats in the experimental group macroscopically retained its anatomical structure. The organ was in close contact with the extra-organ vascular plexus located under the roof and on the walls of the third ventricle in the brain. The pineal gland had an oval shape, but the linear parameters changed. The gland's length decreased by $4.3 \%(1.135 \pm 0.009 \mathrm{~mm} ; \mathrm{P}>0.05)$, the width 


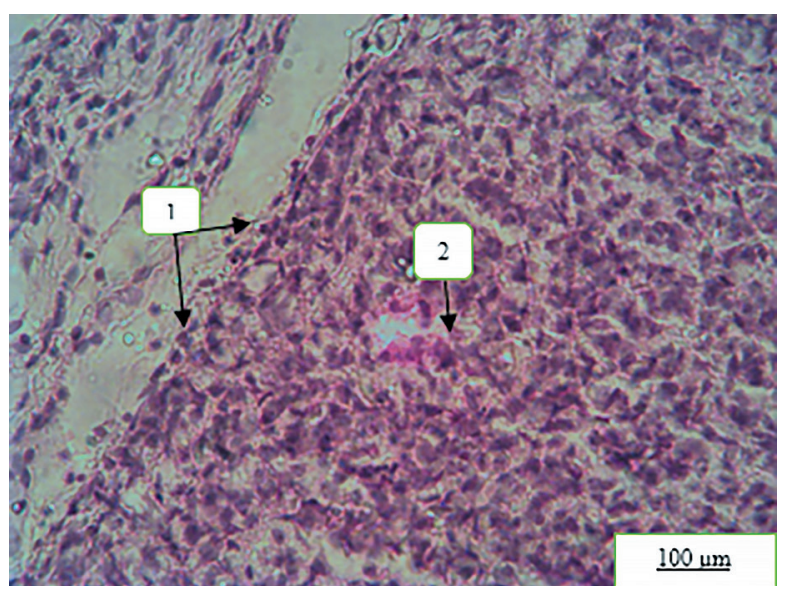

Fig. 1. Morphological rearrangements of the pineal gland's structural components under the condition of 30-days exposure to heavy metal salts:

1 - thickening of the gland capsule; 2 - vascular plethora.

Hematoxylin-eosin staining.

was reliably less by $21.8 \%(0.713 \pm 0.021 \mathrm{~mm}$; $\mathrm{P}<0.001)$ compared to the control animals. Morphological changes in the organ refer to the rearrangements in the stromal, parenchymal and vascular components. In our opinion, it is interesting to compare the detected morphological rearrangements in the pineal gland's structure of the animals in different experimental groups with their morphometric parameters, as well as to find correlations between them. The gland's capsule was thickened, loose, its morphometric parameters $(3.11 \pm 0.232 \mu \mathrm{m})$ were by 2.8 times $(\mathrm{P}<0.001)$ higher than those of the control animals. The intertrabecular spaces were dilated, especially in the peripheral parts of the pineal gland. Initial stages of hemodynamic disorders in the organ were observed, mainly dystonic. Disorders of hemodynamics began with disturbances in the blood filling of the vascular bed, namely with changes in the blood vessels' lumen, moderate plethora of the microcirculatory bed. In the subcapsular, peripheral areas, the lumen of the vessels was dilated, and in the central areas, on the contrary, the vessels were spasmed (Fig. 1). The area of vascular lumen increased by 1.5 times $(\mathrm{P}<0.0001)$ compared to the control animals.

Pinealocytes also underwent morphological rearrangements. Two types of pinealocytes were visualized in the preparations. Pinealocytes with small sized hyperchromic cytoplasm

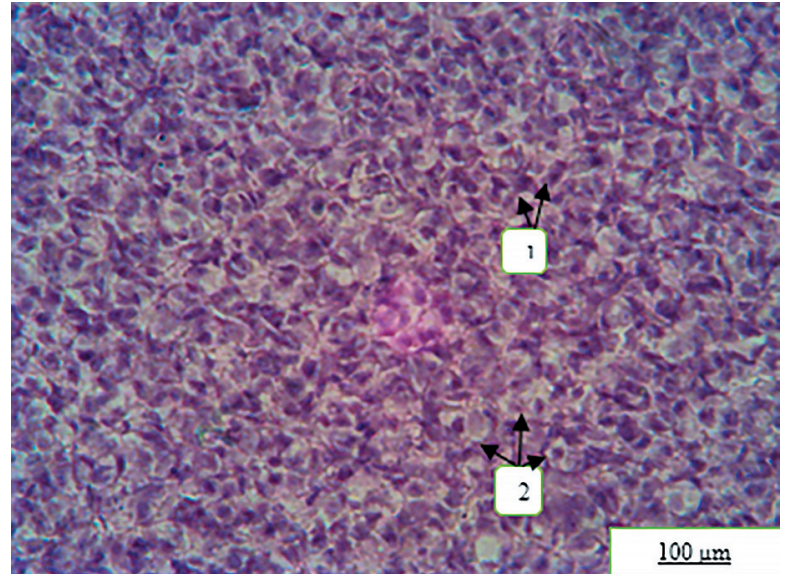

Fig. 2. Morphological rearrangements of the pineal gland's structural components under the condition of 30 days exposure to heavy metal salts: 1 - pinealocytes with signs of indolamine production;

2 - pinealocytes with signs of cytoplasm vacuolation. Hematoxylin-eosin staining.

of triangular shape and hyperchromic angular shaped homogeneous nuclei, increased in size compared to the control, predominated. The nucleolus in such nuclei was not contoured. A small number of pinealocytes had a light cytoplasm, often with signs of vacuolation. In this case, the cytoplasm was filled with a single optically transparent vacuole, colored in light tints. The cell nuclei were enlarged, hypertrophied, of oval or round shape. There was a slight rarefaction of pinealocytes compared to the control. Heavy metal salts caused significant changes in the structure of the nuclear apparatus in the second type pinealocytes. The nuclei karyolemma was slightly thickened, their chromatin network was clarified, saturated with euchromactin, with a hyperchromic, hypertrophied nucleolus located in the center of the nucleus. In some nuclei, the nucleoli were displaced to the karyomembrane. The general morphometric parameters of the nucleus and cytoplasm in pinealocytes are a clear confirmation of morphological changes in the pineal gland (Table). Thus, the index of large diameter of pinealocyte nuclei increases by 2.6 times $(\mathrm{P}<0.001)$, and the index of their small diameter increases by 3.3 times $(\mathrm{P}<0.001)$ compared to the control animals' indices. Indices of large and small diameter of pinealocyte bodies, on the contrary, increase, respectively, by $2.0(\mathrm{P}<0.001)$ and 1.7 times $(\mathrm{P}<0.001)$ com- 
pared to the control animals. Indices of the nuclei intersection area, cytoplasm and pinealocyte bodies increase, respectively, by 6.0 times $(\mathrm{P}<0.0001), 1.8$ times $(\mathrm{P}<0.001)$ and 2.6 times $(\mathrm{P}<0.0001)$ compared to the control animals. The overall indices of the nuclear-cytoplasmic ratio in the cells of both types were $1: 2.3 \pm 0.26$ and decreased compared to the indices of the control animals by 3.3 times $(\mathrm{P}<0.001)$. The optical density of pinealocyte nuclei increased by $31 \%(\mathrm{P}<0.05)$, and cytoplasmic parameters did not practically differ from those of the control animals (Fig. 2).

In the peripheral areas of the gland, especially subcapsularly, there was a slightly increased activity of the glial reaction, which can be considered an active adaptive response of neuroglia to the action of heavy metal salts (Table). A morphometric study of the pinealocytes and astrocytic glia cells number in the pineal gland revealed the following statistical changes: the absolute number of pinealocytes decreased compared to the control animals by $22.3 \%(\mathrm{P}<0.0001)$, and the absolute number of astrocytic glia cells, on the contrary, increased by 1.4 times $(P \geq 0.05)$. Glyocyto-neuronal index increased and exceeded the indices of the control animals by $74 \%(\mathrm{P} \geq 0.05)$.

Thus, 30-day exposure of adult rats to heavy metal salts caused a wide range of morphological changes in all structural components of the gland (parenchyma, stroma and vascular bed). Morphological rearrangements were non-specific polymorphic in nature and indicated the development of adaptive-compensatory processes in the parenchyma of the gland with signs of stress of functional activity. Thus, a dynamic decrease in the linear parameters of the pineal gland in comparison with control animals was recorded. The main and primary stage in the development of negative changes in the pineal gland is undoubtedly vascular disor-

\section{Results of the pineal gland structural components' morphometric study in sexually mature rats under the heavy metal salts impact $(X \pm C D), n=6$}

Table

\begin{tabular}{c|c|c}
\hline \multirow{2}{*}{ Index } & \multicolumn{2}{c}{$\begin{array}{c}\text { Groups of laboratory } \\
\text { animals }\end{array}$} \\
\cline { 2 - 3 } & $\begin{array}{c}\text { Rats of the control } \\
\text { group }\end{array}$ & $\begin{array}{c}\text { Rats of the } \\
\text { experimental } \\
\text { group }\end{array}$ \\
\hline Large diameter of pinealocyte nuclei, $\mu \mathrm{m}$ & $2.53 \pm 0.29$ & $6.62 \pm 0.44^{* * *}$ \\
\hline Small diameter of pinealocyte nuclei, $\mu \mathrm{m}$ & $1.34 \pm 0.04$ & $4.38 \pm 0.3^{* * *}$ \\
\hline Cross-sectional area of pinealocyte nuclei, $\mu \mathrm{m}^{2}$ & $4.45 \pm 0.13$ & $27.02 \pm 8.10^{* * *}$ \\
\hline Large diameter of pinealocyte bodies, $\mu \mathrm{m}$ & $5.26 \pm 0.14$ & $10.57 \pm 0.62^{* * *}$ \\
\hline Small diameter of pinealocyte bodies, $\mu \mathrm{m}$ & $4.12 \pm 0.07$ & $6.98 \pm 0.52^{* * *}$ \\
\hline Cross-sectional area of pinealocyte bodies, $\mu \mathrm{m}$ & $22.73 \pm 0.16$ & $60.41 \pm 13,43^{* * *}$ \\
\hline Area of the pinealocyte cytoplasm, $\mu \mathrm{m}^{2}$ & $18.28 \pm 0.58$ & $33.39 \pm 1.05^{* * *}$ \\
\hline Nuclear cytoplasmic ratio & $1: 4.1 \pm 0.18$ & $1: 1.23 \pm 0.26^{* * *}$ \\
\hline Optical density of the nucleus, RU & $114.09 \pm 1.19$ & $149.42 \pm 14.83^{*}$ \\
\hline Optical density of cytoplasm, RU & $154.06 \pm 0.11$ & $155.14 \pm 6.49$ \\
\hline Vessels area, $\mu{ }^{2}$ & $58.58 \pm 0.42$ & $90.27 \pm 39.65^{* * *}$ \\
\hline Absolute number of pinealocytes & $112.67 \pm 1.93$ & $87.50 \pm 1.87^{* * *}$ \\
\hline Absolute number of astrocytic glia cells & $35.97 \pm 1.95$ & $51.17 \pm 9.91$ \\
\hline Glyocyto-neuronal index & $0.34 \pm 0.44$ & $0.58 \pm 0.84$ \\
\hline
\end{tabular}

Notes:

Reliable compared to the control:

* $\mathrm{p} \leq 0.05$

$* * \quad \mathrm{p} \leq 0.01$

$* * * \mathrm{p} \leq 0.001$. 
ders of dystonic nature (vascular dysfunction, changes in vascular lumen, moderate plethora of the microcirculatory bed), increased area of vascular lumen. These disorders can be considered a consequence of the direct toxic effects of heavy metal salts on the vascular wall, the blood system and according to the authors [6] indicates dysfunctional changes in the reorganization of the gland's secretory activity. Probably, such pronouncement of morphological changes in the vascular bed is connected, first of all, with characteristic features of the pineal gland's circulatory bed, namely - absence of the blood-brain barrier, the lymphatic bed and high blood flow rate. Circulatory disorders led to the initial stages of hypoxic rearrangements in pinealocytes and the stromal component of the gland. Morphometric parameters of the epiphyseal capsule's thickness were reliably higher than those of the control animals, which can be explained by the activation of fibroblasts due to hypoxia and the increased synthesis of intermediate substance and collagen fibers, i.e. the growth of connective tissue. Negative changes in the vascular bed of the pineal gland affected the morphometric parameters of pinealocytes. The pineal gland of group I animals was dominated by pinealocytes with clear cytological signs of indolamine synthesis and the stress of adaptive processes in response to the heavy metal salts impact. These conclusions are made according to the described morphological features of pinealocytes and are based on a number of works by domestic authors. [10, 11]. This is evidenced by a reliable increase in the area of cytoplasm, bodies and nuclei of pinealocytes compared to the control animals. The chronic total effect of heavy metal salts on the pineal gland's pinealocytes in mature rats caused a wide range of morphological changes in the cells' nuclear apparatus. Rearrangements were of polymorphic and nonspecific nature. Morphological changes of chromatin (hyperchromatosis), namely a significant increase in the optical density of chromatin in the nuclei, indicated the initial stages of intracellular bioenergy impairment and a decrease of synthetic and reparative processes in the nucleus. This is an evidence of a decrease in the activity of RNA synthesis and a weakening of the overall controlling effect of the nucleus on the level of pinealocytes' synthetic activity. These rearrangements of the nucleus are hypoxic and associated with genotoxic impact of heavy metal salts on the regulation of synthetic cell activity and the course of the general adaptation syndrome in the body. In the parenchyma of the gland, especially in the subcapsular area and around the vessels, there was a slight degree of reactive astrocytic glial response, which can be considered an active adaptive response of neuroglia to the impact of heavy metal salts [12]. According to the literature [13], this pronouncement of the glial response in this particular area of the gland was explained by the participation of epiphyseal glia in the formation of the barrier zone in the ventricular area of the pineal gland, perivascular and external subarachnoid spaces. There was an increase in the number of astrocytes, a slight decrease in the number of pinealocytes and an increase in the gliocyto-neuronal index compared to the similar indices of the control animals.

\section{CONCLUSIONS}

The effect of a heavy metal salts combination salts on the body caused negative morphological changes of nonspecific polymorphic nature in the pineal gland of mature rats, which were expressed in the increased vascular area, active glial response, hypertrophy of pinealocyte nuclei and increase of their optical density. Cytological signs of most pinealocytes indicated the predominance of indolamine synthesis over polypeptides. The main pathogenetic mechanisms of the influence of heavy metal salts on the organ have been established: change in the vascular lumen area, blood rheological properties impairment, tissue hypoxia, nucleus hypertrophy and change in their optical density. Morphological rearrangements in the gland correspond to the stress phase of the general adaptation syndrome. The above morphological changes in the pineal gland's structural components negatively affect the processes of hormones evacuation into the blood, the course of the general adaptation syndrome and homeostasis restoration in the organ. The studies of the pineal gland, of course, expand the 
range of knowledge about the participation of this central neuroendocrine system's organ in the body's adaptive response to the combination of heavy metal salts and encourage researchers to seek for new drugs to correct morphological changes in the organ.

\section{REFERENCES}

1. Yan X, Liu M, Zhong J, et al. North China 2018;10(2): 338. https://doi.org/10.3390/su10020338.

2. Romanyuk AM, Hryntsova NB, Karpenko LI, et al. Problems of Endocrine Pathology 2019;2: 98-103. https:// doi.org/10.21856/j-PEP.2019.2.14.

3. Rehman K, Fatima F, Waheed I, Akash MSH. J Cell Biochem 2018;119(1): 157-184. https://doi.org/10.1002/ jcb.26234.

4. Wan D, Han Z, Yang J, et al. Int J Environ Res Publ Health 2016;13(11): 1119. https://doi.org/10.3390/ijerph 13111119.

5. Hryntsova NB, Timakova OO, Romanyuk AM. Problems of Endocrine Pathology 2020;4: 106-114. https://doi. org/10.21856/j-PEP.2020.4.14.

6. Gheban BA, Rosca IA, Crisan M. Medicine and Pharmacy Reports 2015;92(3): 226-234. https://doi.org/10. 15386/mpr-1235.

7. Volkov VP. Universum: Medicine and Pharmacology electron. Scientific 2014;9 (10), available at: http://7universum.com/en/med/archive/item/1590.
8. Pshichenko VV. Kuban Scientific Medical Bulletin 2014; 1(143): 150-154.

9. Chlubek D, Sikora M. Applied Science 2020;10(2885): 1-10. https://doi.org/10.3390/app10082885.

10. Gubina-Vakulik GI. Bukovina Medical Bulletin 2006; 10(4): 34-36

11. Bondarenko AA, Gubina-Vakulik GI, Gevorgyan AR. Pineal gland and hypothalamic-pituitary-thyroid system: age and chronobiological aspects, Kharkiv, 2013: 262.

12. Goryainov SA, Protsky SV, Okhotin VE. Anal Clin Experim Neur 2013;7(1): 45-51.

13. Drozdova GA, Samigullina AF, Nurgaleeva EA. Kazan Med $J$ 2017; 98(6): 984-988 https://doi.org/10.17750/ KMJ2017-98.

\section{ОСОБЛИВОСТІ МОРФОЛОГІЧНИХ ПЕРЕБУДОВ СТРУКТУРНИХ КОМПОНЕНТІВ ЕПІФІЗА ЩУРІВ ЗА УМОВИ ВПЛИВУ СОЛЕЙ ВАЖКИХ МЕТАЛІВ}

Гринцова Н. Б. ${ }^{1}$, Романюк А. М. ${ }^{1}$, Ходорова И. ${ }^{2}$, Карпенко Л. І. ${ }^{1}$, Дмитрук С. М. ${ }^{1}$, Бумейстер В. I. ${ }^{1}$, Зайцева C. С. ${ }^{1}$

${ }^{1}$ Сумський держсавний університет, медичний інститут, м. Суми, Украйна

${ }^{2}$ Університет ім. П. Й. Шафарика в Кошице, м. Кошице, Словаччина natalia.gryntsova@gmail.com

Розвиток патології окремих органів та систем організму детермінують ксенобіотики, в тому числі і солі важких металів. Гормони епіфіза займають одне з ключових місць у регуляції та підтриманні основних функцій організму. Метою дослідження стало вивчення морфологічних та морфометричних перебудов структурних компонентів епіфіза статевозрілих щурів в умовах впливу солей важких металів.

Матеріали та методи. Експеримент проводили на 12 білих статевозрілих самцях щурів вагою 200-250 г у віці 7-8 місяців, які були розділені на 2 групи (контрольна та експериментальна). Тваринам експериментальної групи моделювали мікроелементоз шляхом додавання до питної води суміші солей важких металів протягом 30 діб: цинку $\left(\mathrm{ZnSO}_{4} 7 \mathrm{H}_{2} \mathrm{O}\right)-5$ мг/л, міді $\left(\mathrm{CuSO}_{4} 5 \mathrm{H}_{2} \mathrm{O}\right)-1$ мг/л, заліза $\left(\mathrm{FeSO}_{4}\right)-10$ мг/л, марганець $\left(\mathrm{MnSO}_{4} 5 \mathrm{H}_{2} \mathrm{O}\right)-0,1$ мг/л, свинець $\left(\mathrm{Pb}\left(\mathrm{NO}_{3}\right)_{2}\right)-0,1$ мг/л та хром $\left(\mathrm{K}_{2} \mathrm{Cr}_{2} \mathrm{O}_{7}\right)-0,1$ мг/л. Застосовували загальноморфологічні та статистичні методи дослідження (гістологічний, морфометричний та статистичний).

Результати. 30-ти добовий вплив на організм щурів комбінації солей важких металів викликав у епіфізі морфологічні перебудови неспецифічного поліморфного характеру, що виражалися у збільшенні площі судин, активній гліальній реакції, гіпертрофії ядер пінеалоцитів та збільшенні їх оптичної щільності. Цитологічні ознаки більшості пінеалоцитів вказували на переважання синтезу індоламінів над поліпептидами. Встановлені основні патогенетичні механізми дії солей важких металів на орган: зміна площі просвіту судин, порушення реологічних властивостей крові, тканинна гіпоксія, гіпертрофія ядер та зміна їх оптичної щільності.

Висновки. Морфологічні перебудови в залозі відповідають фазі напруження загального адаптаційного синдрому. Вищевказані морфологічні зміни структурних компонентів епіфіза негативно вплинули на процеси евакуації гормонів у кров, перебіг загального адаптаційного синдрому та відновлення гомеостазу в органі.

Ключові слов а : важкі метали, гіпоксія, індоламіни, адаптація, епіфіз. 


\section{FEATURES OF MORPHOLOGICAL REARRANGEMENTS OF STRUCTURAL COMPONENTS IN THE RAT PINEAL GLAND UNDER THE IMPACT OF HEAVY METAL SALTS}

N. B. Hryntsova ${ }^{1}$, A. M. Romanyuk ${ }^{1}$, I. Hodorova ${ }^{2}$, L. I. Karpenko', V. I. Bumeister ${ }^{1}$, S. M. Dmytruk ${ }^{1}$, S. S. Zaitseva ${ }^{1}$

${ }^{1}$ Sumy State University, Medical Institute, Sumy, Ukraine

${ }^{2}$ Pavel Josef Shafarik University in Kosice, Kosice, Slovak Republic natalia.grintsova@gmail.com

The development of the pathology of individual organs and systems undoubtedly depends on adverse environmental factors. Particular attention of researchers attracts heavy metal salts. Epiphyseal hormones play a key role in regulating and maintaining basic body functions. The study was to elucidate the morphological and morphometric rearrangements the structural components changes in the pineal gland of mature rats under the influence of heavy metal salts.

Materials and methods. The experiment was performed on 12 white mature male rats weighing 200-250 g at the age of 7-8 months, which were divided into 2 groups (group 1 control and group 1 experimental). Animals of the experimental group were simulated microelementosis by adding to drinking water a mixture of heavy metal salts for 30 days: zinc $\left(\mathrm{ZnSO}_{4} 7 \mathrm{H}_{2} \mathrm{O}\right)-5 \mathrm{mg} / \mathrm{L}$, copper $\left(\mathrm{CuSO}_{4} 5 \mathrm{H}_{2} \mathrm{O}\right)-1 \mathrm{mg} / \mathrm{L}$, iron $\left(\mathrm{FeSO}_{4}\right)-10 \mathrm{mg} / \mathrm{L}$, manganese $\left(\mathrm{MnSO}_{4} 5 \mathrm{H}_{2} \mathrm{O}\right)-0.1 \mathrm{mg} / \mathrm{L}$, lead $\left(\mathrm{Pb}\left(\mathrm{NO}_{3}\right)_{2}\right)-0.1 \mathrm{mg} / \mathrm{L}$, and chromium $\left(\mathrm{K}_{2} \mathrm{Cr}_{2} \mathrm{O}_{7}\right)-0.1 \mathrm{mg} / \mathrm{L}$. General morphological and statistical research methods were used (histological, morphometric and variational statistics methods).

Results. The 30-days impact of the heavy metal salts combination on the rat body caused in the pineal gland morphological changes of nonspecific polymorphic nature, which were expressed in the increased vascular area, active glial response, hypertrophy of pinealocyte nuclei and increase of their optical density. Cytological signs in most pinealocytes indicated the predominance of indolamine synthesis over polypeptides. The main pathogenetic mechanisms of the influence of heavy metal salts on the organ have been established: change in the vascular lumen area, blood rheological properties impairment, tissue hypoxia, nucleus hypertrophy and change in their optical density.

Conclusions. Morphological changes in the gland comply with the stress phase of the general adaptation syndrome. The above morphological changes negatively affected the processes of hormones evacuation into the blood, the course of the general adaptation syndrome and the homeostasis restoration in the organ.

Key words: heavy metals, hypoxia, indolamine, adaptation, pineal gland. 